\title{
CRYAB Gene
}

National Cancer Institute

\section{Source}

National Cancer Institute. CRYAB Gene. NCI Thesaurus. Code C115113.

This gene is involved in lens formation. 